\title{
Wesley in Oxford and the Legend of Holy Grail's Knight: The Study about the Root of Methodism to the World, and the Foundation of Kwansei-Gakuin in Japan
}

\section{Dr. Kawanishi Takao}

Ph.D. Fellow, Kwansei-Gakuin University, Japan

Doi:10.5901/ajis.2017.v6n1p9

\section{Abstract}

John Wesley (1703-91) is known as the founder of Methodism in his time of Oxford University's Scholar. However, about his Methodical religious theory, he got more spiritual and important influence from other continents not only Oxford in Great Britain but also Europe and America. Through Wesley's experience and awakening in those continents, Methodism became the new religion with Revival by the spiritual power of "Holy Grail". By this research using Multidisciplinary approach about the study of Legend of Holy Grail's Knight, - from King Arthur and Knights of the Round Table in the Medieval Period, and in 18th century Wesley, who went to America in the way on ship where he met the Moravian Church group also called Herrnhut having root of Pietisms, got important impression in his life. After this awakening, he went to meet Herrnhut supervisor Zinzendorf (1700-60) in Germany who had root of a noble house in the Holy Roman Empire, - and to Legend of Holy Grail's Knight Opera "Parsifal" by Richard Wagner at Bayreuth near Herrnhut's land in the 19th century, Wesley's Methodism is able to reach new states with the legend, such as the historical meaning of Christianity not only Protestantism but also Catholicism. I wish to point out Wesley's Methodism has very close to Legend of Holy Grail's Knight. In addition, after the circulation in America, in the late 19th century Methodism spread toward Africa, and Asian Continents. Especially in Japan, by Methodist Episcopal Church South, Methodism landed in the Kansai-area such international port city Kobe. Methodist missionary Walter Russel Lambuth (1854-1921) who entered into Japan founded English schools to do his missionary works. Afterward, one of them became Kwansei-Gakuin University in Kobe. Moreover, Lambuth such as Parsifal with Wesley's theories went around the world to spread Methodism with the Spirit's the Legend of Holy Grail's Knight as World Citizen.

Keywords: John Wesley, Oxford University, Methodism, Legend of Holy Grail's Knight, Revival, Moravian Church (or Herrnhut), Zinzendorf, Parsifal, Methodist Episcopal Church South, Walter Russel Lambuth, Kwansei-Gakuin University

\section{Wesley and Methodism - from the View of Preceding Research, to this Multidisciplinary Approach}

\subsection{Did Wesley found Methodism in Oxford University, and why \& how it spread around the world?}

Methodism is said generally that John Wesley (Wesley, 1703-91) founded in Oxford University, where he supervised religious society named Holy Club (1729-) with his brother Charles Wesley (1707-88). Also George Whitefield (1714-70) known later by The Great Awakenings having root of Wesley's Revival and Holiness movement, as their Club member in this University succeeded and spread Wesley's Methodism. So, Wesley's Methodism was regarded to be made and rise at Oxford University.

In addition, the main doctrine of Methodism is put importance on the method of Christianity of the New Testament. Thus, Methodism is considered one of Protestantism wings in root of Martin Luther (1483-1546) ${ }^{1}$. Besides, it was said the believer is methodical, therefore, called Methodist ${ }^{2}$.

However, is it correct position that Methodism is simply one of Protestantism? And, was Methodism historically made in Oxford University only? Moreover, the influence of Zinzendorf (Nikolaus Ludwig von Zinzendorf, 1700-60) and

${ }_{1}^{1}$ Preceding research about Wesley and Methodism is so many and interestingly even now. Most of them, Methodism is positioned such as Protestant recovery or revival of Protestantism from the Reformation time. For example, Kent, Wesley and the Wesleyans, 1-30, 187207. Tuttle. John Wesley, His life and Theology, 23-77, 85-126.

${ }^{2}$ Another Preceding research explains Methodism from the side of Puritanism by Jean Calvin (1509-1564) or Arminianism by Jacobus Arminius (1560-1609). Monk, John Wesley His Puritan Heritage. McGonigle, Sufficient saving grace: John Wesley's evangelical Arminianism. 
his community Herrnhut consisted member of the Moravian Church (Unitas Fratrum, Herrnhuter Brüdergemeine) was so limited to Methodism according to preceding research.

My thesis tries to rethink and give new perspective about Methodism, not only these traditional and domestic points, but also religious importance in the world from the viewpoint of the Legend of Holy Grail's Knight having the root of the Holy Grail of Christianity and Moravian Church including Herrnhut community with the Eucharist. Moreover, I want to state that the method on Methodism has deep meaning from the foundation of Christianity about 2000 years ago.

\subsection{The step from the preceding research about Wesley and Methodism}

Until now, about Methodism conception, above mentioned, was regarded as one part of Protestantism in the $18^{\text {th }}$ century in England at Industrial Revolution. At the time people's life drastically changed to seek a better job and wages from countryside to industrial city, thus the existing social and religious structure lost the base for the original community. So, the preceding research said that Methodism was appeared as new Protestantism to adjust in modern time.

However, I think that it is not enough because Methodism has old root such as Herrnhut in German east border and Moravian natural countryside in Czech, not industrial city like London, Manchester in Great Britain. In addition, this Herrnhut supervisor Zinzendorf has roots of old Imperial Aristocracy from Austria and Knight named "Graf' in his territory, not the capital supervisor of industrial factory ${ }^{3}$.

And next, Wesley's Methodism got believers over the continents, Britain, Europe, and America in the $18^{\text {th }}$ century. After in 19-20th century spread from Asia, especially, China, and Japan, reaches to Africa continent. From this point of view Methodism had a possibility as Global Religion in the new Era beyond Industrial Revolution's time. In addition, Methodism has the historical root not only Moravian Church and Herrnhut community, but also the old root of Christianity over Luther's Protestantism. I also point out this root related in the Holy Grail's worship of Christ, following.

\subsection{New approach from Legend of Holy Grail's Knight to Spirit of Methodism}

The Legend goes back to the time of the Passion of Christ in Jerusalem, in this Last Supper, Christ said to the apostles about his sacrifice using Grail (after his death, called the Holy Grail received his blood in crucifixion) ${ }^{4}$. However, the Holy Gail's worship was not permitted by orthodox on the New Testament. This Grail worshiper was regarded as a heresy by Catholics.

In spite of this situation, the worshiper called Eucharist ${ }^{5}$, or Utraquist (in the $15^{\text {th }}$ century) remains to keep believing and worship in the outside of the orthodox-area, or mountain on and on. This Holy Grail's worship evolved as Legend of Holy Grail's Knight such as King Arthur and Knights of the Round Table in England, and Perceval in France, Parzival in Holy Roman Empire, and Parsifal in Germany nowadays.

At the Christian Millennium time in the $11^{\text {th }}$ century, one of a noble house with the worship of the Eucharist and Legend of Holy Grail's Knight appeared in the middle of Europe, it was House of Andechs-Meran which supported Staufen Holy Roman Empire in Italy 6 . Staufen and Andechs-Meran aimed new Millennium's World Order of the Empire under Legend of Holy Grail and these Knights such as Parzival's story under mutual cooperation and prosperity of the world beyond religion?

However, orthodox-supporter and anti-Empire attacked to Andechs-Meran and Staufen, at last, both finished in the half of the $13^{\text {th }}$ century and escaped to the outside keeping the worship. In the $15^{\text {th }}$ century, at Bohemia, Hussite religion War happened in Prague. This one wing of Hussite named Utraquist which rooted Eucharist did not fight and demand peaceful reconciliation. After this war, Utraquist survived and concealed in Moravian area ${ }^{8}$. Those who called the Moravian Church gave the strong influence to Zinzendorf and Wesley ${ }^{9}$ in the $18^{\text {th }}$ century.

\footnotetext{
${ }^{3}$ Hahn \&Reichel (Hrsg), Zinzendorf und die Herrnhuter Brüder, 16-28.

${ }^{4}$ Rubin, Corpus Christi, The Eucharist in late Medieval Culture, 139-142, 294-334, 316-346. And, Adams, Some Later Medieval Theories of the Eucharist.

${ }^{5}$ O'Connor, The Eucharist in the Primitive Church, 141-165. In this research insisted the existence about Eucharistic Manners or Method roots from Jewisch Culture before Christ's Time.1-21.

${ }^{6}$ Bayerische Staatskanzlei (Hrsg), Herzöge und Heilige. Das Geschlecht der Andechs-Meranier im europäischen Hochmittelalter. Hennig, Die Andechs-Meranier in Franken. Europäisches Fürstentum im Hochmittelalter.

7 Wolfram von Eschenbach, Parzival.

${ }^{8}$ In 1457, Unitas Fratrum (Moravian Church) was founded at Kunvald in Czech north border where was land of King George of Poděbrady (Podiebrad, 1420-71) who was Utraquist, and opposed to the radical wing of Hussite.

${ }_{9}^{9}$ Moravian Church and Herrnhut influenced not only Zinzendorf and Wesley but also Comenius (1592-1670), Goethe (1749-1832), Jean

Paul (1763-1825), Schleiermacher (1768-1834) etc.
} 


\section{Wesley in Oxford University and his Awaking by Moravian Church with Holy Grail Worship such as Revival}

\subsection{The root of Oxford University and Legend of Holy Grail's Knight}

Oxford University, founded in the $12^{\text {th }}$ century was oldest in England. At the time, Historiae Regum Britanniae (The History of the Kings of Britain) by Geoffrey of Monmouth in Oxford ${ }^{10}$ which became one of original King Arthur Story appeared. Afterward, the story had with a part of Legend of Holy Grail's Knight rooting Christianity. From late $12^{\text {th }}$ century in Europe, the story of Legend of Holy Grail's Knight was written such as Perceval ${ }^{11}$, and Parzival. And finally in $15^{\text {th }}$ century, the complete story of Legend of Arthur and Grail's Knight named Le Morte d'Arthur was produced by Thomas Malory (CA. 1415-71) in England.

On the other hand, in Oxford University, they talked about the Reformation of Christianity, in the $14^{\text {th }}$ century, Wycliff (CA.1330-84) appeared and influenced to Hus (CA.1370-1415) in Bohemia including Utlaquist above mentioned.

In early $18^{\text {th }}$ century, Wesley studied in Oxford, and he participated Holy Club for seeking religious piety. This Club or Holy Communion such as Eucharist meet together and celebrated the Mass in Christ church at Oxford ${ }^{12}$, this scene reminds Legend of King Arthur, and Knights round the table to pray Holy Grail Mass, where Geoffrey of Monmouth existed.

In 1735 Wesley went to Georgia in American continent for mission, on the way, Wesley who first contacted settlers of Moravian Church saw this group on the ship in heavy storm. At the time he got strong impression from their Pietism because they did not fear of death, and kept to pray and sing for God.

By the way, it was said that Wesley completely failed the mission and his life at Georgia ${ }^{13}$. However, I do not think because he got important experiences in his way going to the new continent. Following, Wesley met various characters of -

1) Moravian church(Herrnhut) member in the ship and Savannah, above mentioned, Wesley could know well their religion having the root of Holy Grail ${ }^{14}$.

2) Indian (as aborigines), African (under slavery), European (as emigrant or prisoner) etc.

3) Nature in the new large and innocent continent of America

And, Wesley went through the ordeal about love and marriage problem with emigrant's woman. Thus, he left from there like a runaway, went back to England. After these experiences, he became strong against hardship, and had human tolerance and universality, finally build the Methodism as world religion. Also this trial of Wesley and the woman reminds Parsifal(Parzival) and Kundry(Kundrie) awaked Parsifal on Legend of Holy Grail's Knight.

\subsection{The Wesley's Revival and Spiritual Holy Grail's Power}

The second impression on Wesley was in 1738 at London Moravian Church meeting in Aldersgate Street. It was known the first time of the Revival on Wesley. In the year (1738), Oct 9, Wesley wrote "While at Oxford I soon saw miracle..., all of whom sought salvation only in the blood of Christ". This suggests Wesley realized Miracle Power and Legend of Holy Grail filled Blood of Christ. In the same time, Revival became so large. He also wrote "The revival began! For nearly two months I had been preaching... totalling nearly 50,000 a week"15. However, Wesley did not use the name of "Holy Grail". About this reason, I think Holy Grail Worshiper regarded as Heresy such as Catharism or Gnosticism by the authority and the people ${ }^{16}$, thus Wesley avoid the name and he used another symbolic name such as Holy Spirit etc. instead of Holy Grail.

Afterward, Wesley went Europe to see Moravian Church community, Heerendijk in Holland, Marienborn and Herrnhut in Germany, and met the supervisor Graf Zinzendorf.

It is said that this meeting was not so good for two. At this time Wesley felt Herrnhut of Zinzendorf like heresy as Quietism. In another, Wesley noticed to be a class difference between Wesley as one cleric from England, and the Holy

\footnotetext{
10 Lupack, The Oxford Guide to Arthurian Literature and Legend, 24-25. And it was said that Geoffrey stayed and taught in Oxford from 1129 to 1151 about 20 years in Oxford University's foundation time.

${ }^{11}$ Chrétien de Troyes, Le Roman de Perceval ou Le Conte du Graal.

${ }_{12}$ Hammond, John Wesley in America: restoring primitive Christianity, 50-64. Wesley's Eucharistic Doctrine and Practice.

13 Tuttle, 141-142.

${ }_{14}$ Hammond, 124-127. True and Historical Narrative of the Colony of Georgia on Wesley's Eucharistic Practice.

15 Tuttle, 249-250.

${ }^{16}$ Barber, The Holy Grail -The History of a Legend, 138-139, 144-147. Baigent, Leigh, Lincoln, Holy Blood, Holy Grail, 383-385.
} 
Roman Empire nobleman Zinzendorf having old roots of an aristocrat in Austria17.

Wesley, however, who talked with the Zinzendorf and his member ${ }^{18}$ in Europe or America should have deeply impressed and respected in the Moravian Church and Herrnhut community rooting Pietism, Eucharist and Utraquism with the legend of the Holy Grail in these lands ${ }^{19}$. And he should feel the aristocrat Zinzendorf as Holy Grail's Knight or King for protecting his Holy Communion of Herrnhut having root of Holy Grail's worship.

Through Wesley's experiences of America and Europe by Moravian Church (Herrnhut) and Zinzendorf, his Methodism developed and became globally beyond borders and continent.

After Wesley, in 1795 Methodism separated and was independent from the Anglican Church. In addition, Methodism and Oxford movement in $19^{\text {th }}$ century promoted the Anglican Church to change of the stance to close relation with Roman Catholic Church. Thus, Methodism had the important role of the European Christianity and new Protestantism in civilian individualism and democracy Era.

On the other hand, it must be emphasized that Revival in Holiness movement by Wesley played essential roles at a Methodism foundation time and the next centuries spreading in the world. The Holiness movement is important of Miracle by the Holy Spirit in Trinity, which was developed by Revival in humankind ${ }^{20}$. Wesley also rode in his horse with the Bible such as Holy Grail's Knight from town, factory, or prison to forest, hill or fields like Jesus Christ to lead and save all people by Revival ${ }^{21}$. In his sermon place, it had so many hymn to sing for God. It also reminds Legend of Holy Grail's Knights consisted music or chorus scenes such as Parsifal.

And, I can say that the civilian sought Wesley the Miracle as the new religion from God. Also Wesley sometimes showed the Miracle of Eucharistic Mass in the church or another place. It is called Revival by the Holy Spirit in Holy Grail's Power through Mysticism and Pietism from Christianity. Moreover, I mention that the gathering people were dramatically awake called The Great Awakenings and clearly felt at the Holy Grail Mass in the time of the Passion and Revival of Christ.

\subsection{Methodism and Freemasonry, related to the Holy Grail}

One more interesting and remarkable thing is the relationship between Methodism and Freemasonry. Generally, it was said both are in opposition. However, both founded (appeared) in the same time in England, after spread, especially in America, having a root of the European Eucharist as Holy Grail legend and Mysticism from monotheism or Jerusalem ${ }^{22}$. In addition, Freemasonry also puts on the importance of the method of believers(members). Moreover, nowadays both became so global as a new religion and faith under Cosmopolitanism.

When John Wesley decided to go to Savannah at Georgia, this request was from James Oglethorpe (1696-1785) of British general and the founder of the colony of Georgia, who was Freemasonry and founded Solomon's Lodge in Savannah at 1734. It was first Masonic Lodge in Georgia colony. The next year (1735), Wesley and brother Charles came in Savannah. Also Charles who was well known as a hymn writer for Methodist worked with Oglethorpe at there ${ }^{23}$. Thus, it can say that both founders of Methodism were very related and supported by Freemasonry. In addition, Herrnhut community existed in the time at Savannah. It suggests Three (Freemason, Methodist, Herrnhut) knew well each other and had relationship in the new continent such as New Jerusalem in the New Testament.

However, the difference of both exists, following.

i) Methodism is Christianity, but Freemasonry is Monotheism including Islam or Jewish, etc.

ii) Methodism is openly religious membership, but Freemasonry is closely like secretive, in general.

As one of result, both are different, but the same is many, it is not strange both had some good cooperation from the founding time above mentioned.

\footnotetext{
17 Turner, John Wesley: the evangelical revival and the rise of Methodism in England, 30-31.

${ }^{18}$ such as Peter Böhler (1712-75), A. G. Spangenberg (1704-1792), etc.

19 Tuttle, 203-214.

20 Turner, 1-19.

${ }^{21}$ Church, Knight of the burning heart: the story of John Wesley.

22 Barber, 135-147, 291-292, 307-309.

23 Tuttle, 130-136.
} 


\section{Methodism and Parsifal in 19-20 th Century and Revival in Japan}

\subsection{Parsifal as Revival of Eucharist}

Above mentioned in 2.2), after Wesley, Methodism continued to expand by the successors doing Revival from Oxford to Great Britain, Europe and America since the $18^{\text {th }}$ century ${ }^{24}$.

In the late in the $19^{\text {th }}$ century in east border Germany, near Herrnhut in Saxony, the Legend of Holy Grail's Knight named Parsifal (1882-) revived as Opera at Bayreuth25 Festival by Richard Wagner (1813-1883) who was born in Saxony and studied about the Legend such as Perceval and Parzival. This Parsifal which Wagner completed as his last work also named Bühnenweihfestspiel (the festival play for the consecration of the stage) at Bayreuth, is not normal Opera, but sacred ritual and Revival in Church such as Eucharistic Mass for the legend of the Holy Grail and Knight ${ }^{26}$. In addition, Parsifal's story has the worship of the Holy Wounds (Stigmata) in the Mass as well as Herrnhut by Zinzendorf also having a root of the Legend and Primitive Christianity.

From the first stage Parsifal got success continuously, this Eucharistic Revival's Opera was also imagined Methodism above mentioned. Parsifal was strongly demanded the performing stage in America, England and another city of Europe in spite of regulation of law. These successes of Parsifal having the root of the Eucharist also can say that people in modern time sought relief of the soul each other which Wagner's Parsifal got Mitleid through the Passion of Christ including his Blood from Holy Wounds symbolized Holy Grail (Eucharist) Mass 27.

\subsection{The Expansion of Methodism in China and Japan by family Lambuth}

Thus, for the same time of Parsifal's success, from America, Methodism began to spread globally to Asia, Africa, and Eurasia etc.

At this time, one of Methodist key person like Parsifal named Walter Russel Lambuth (Lambuth, 1854-1921) was at Shanghai in China having American national. His Family member belonged Methodist Episcopal Church, South in America for generations ${ }^{28}$. After Lambuth graduated University in America, he went back to China in 1877 as a medical missionary. In 1886, he and his spouse went to West Japan for mission of Methodist, and the next year he planned to build colleges in important city for educating Japanese as Methodist missionary. Then at 1889 in Kobe, Lambuth founded the Methodist college Kwansei-Gakuin (in now, University) and assumed the first chairman ${ }^{29}$. It can say that Lambuth took over the Spirit and Mission of John Wesley to propagate Methodism and develop as Missionary or Medical school, such as University or Hospital in the future from American continent to other continents. As the Missionary in the time, Japan was important place to link these continents by sea route.

\subsection{The Revival by Lambuth such as Legend of Holy Grail's Knight}

At the end of year in Kwansei-Gakuin's foundation, about 4 p.m. 31st. Dec.1889, at the Church in Ōita Prefecture, Lambuth occurred the miraculous phenomenon called "Ōita Revival". It was said that the gathering believers were awake by spiritual brightness from God and were moved to tears, converted Methodist ${ }^{30}$. It seems Lambuth had the ability of Revival using Eucharistic and Holy Grail's Power such as Wesley's Revival, And I can say that Lambuth aimed to complete the foundation of the Japanese Methodist University with Holy Grail's Power.

In addition, this Oita City is also known to have old Christian Historical place in Japan where in $16^{\text {th }}$ Century Daimyo (Clan of Samurai) Ōtomo met Francisco Xavier (1506-1552) of the Society of Jesus from Vatican in Rome, and permitted to trade with Europe and to build a Catholic church in this city to propagate of Christianity in his territory. This suggests that Lambuth should know well about the old Christian history in Japan and felt important meaning to occur Revival at new Methodist church in this city where was very close to the Catholic church. I can say that Ōita Revival by

\footnotetext{
${ }^{24}$ Raedel, Methodistische Theologie im 19 Jahrhundert, 341-356.

25 Trübsbach, Geschichte der Stadt Bayreuth.

${ }^{26}$ Csampai \& Holland, Parsifal Texte,Materialien,Kommentare.

${ }^{27}$ Kawanishi, Academic Journal of Interdisciplinary Studies, 361-369.

${ }_{28}^{8}$ Norwood, The Story of American Methodism, 205-207.

${ }^{29}$ Kwansei Gakuin University Overview 2013, 2-3.

30 Pinson, Walter Russell Lambuth, Prophet and Pioneer.
} 
Lambuth meant Revival of Christianity in Japanese history by Methodist.

On the other hand, after this foundation of Methodist University (College at the time, above mentioned) in Japan, Lambuth went another country as a Methodist Missionary to Brazil (from 1894, 6time), Cuba $(1898,18$ time), CentralAfrica (1910), Congo (1914), Mexico (1914, 16time), Paris (1918), Siberia (1920), etc.

His great works showed us religious peace keeping and educational, medical mission in his time around the world such Parsifal as World Citizen beyond the border and religious and tribal prejudice ${ }^{31}$. Also, in Wagner's Parsifal, by Compassion (Mitleid) to Christ's blood as Holy Grail, it is expressed to bring the real peace and happiness as human under Cosmopolitanism.

\section{Conclusion - Methodism and the Mission of $21^{\text {st }}$ century - through Methodist University of Kwansei-Gakuin in Japan}

\subsection{From Oxford's Methodism to Kwansei-Gakuin motto -Mastery for Service-}

Nowadays, Oxford and Kwansei-Gakuin maintains the academic cooperation. In this background of contract, it can say that both universities directly relate to Methodism above mentioned. Wesley's Methodism in Oxford in the middle of the $18^{\text {th }}$ century was brought to Kwansei-Gakuin in Japan in the late in the $19^{\text {th }}$ century.

By the Kwansei-Gakuin founder Rambuth who was missionary and pioneer such as Parsifal of Legend of Holy Grail's Knight, Methodism with the soul of Wesley spread in Japan.

Mastery for Service- It is the Motto of Kwansei-Gakuin in 1912 by the $4^{\text {th }}$ chairman C.J L. Bates (1877-1963) who was a Methodist Missionary from Canada. Until now, this motto was interpreted various meanings with the thought of the times over a hundred year ${ }^{32}$. As for ordinary Japanese with Buddhism and Shintoism, this Motto was so difficult.

However, above mentioned, the original Wesley's Methodism in Oxford was strongly influenced by Moravian Church and Herrnhut community, Utraquist and Eucharist, having the root of the Holy Grail's legend. Thus, Mastery for Service has common values of Christianity, and means to serve completely for Jesus Christ and his sacrifice symbolized in Holy Grail such as Legend of Holy Grail's Knight.

\subsection{The Kwansei-Gakuin University's Emblem and Legend of Holy Grail's Knight}

This motto also is symbolized the University's Emblem by Bates in 1929 which mainly consists 5 parts.

1) The emblem's background is Christian Cross, which is main symbol means Christianity, moreover the emblem or flag of Christian Cross reminds Christian Knight such as Legend of Holy Grail's Knight. And the emblem divides 4 sections by the Cross, following.

2) In the 1 section is drawn the Bible in New and Old Testaments meaning Christianity and Judaism.

3) 2 is a Crescent Moon, which also reminds Islamism or other Oriental religion. According to Kwansei-Gakuin, this Crescent is an old school badge since 1894 at the time of Lambuth. And this means that people are growing up to perfect human as well as Crescent finally becomes the full Moon. It is the very same story of Parsifal and Legend of Holy Grail's Knight that Parsifal is growing up to the Knight, and become Holy Grail's King at last 33 .

4) 3 is the Sacred Fire in torch means Humankind (using fire) and Natural Power

5) 4 is a Stick of Hermes means Human Wisdom and Mysticism such as Hermes Trismegistus to reach Freemasonry above mentioned 2.3.

So, the emblem appears that the Spirit of Kwansei-Gakuin is not only Methodism of Christianity, but also World Mysticism of Human and Nature, Universe, and to reach in Cosmopolitanism, and the Creator. In addition, above mentioned, the Spirit of Kwansei-Gakuin University is familiar with Legend of Holy Grail's Knight.

${ }^{33}$ According to Steiner, Moon is Symbol of Holy Grail. Christus und die geistige Welt: Von der Suche nach dem heiligen Gral. 


\subsection{Methodism and the Legend from Kwansei-Gakuin's Mission in nowadays}

In conclusion, it must reconsider why in Japan Methodism University Kwansei-Gakuin with the Legend was built in the late in the $19^{\text {th }}$ century? It makes feel that more important meaning exists not only Japan but also countries around the world. At the time in Japan and another country, Nationalism and Xenophobia became so strong and began to war.

On the contrary, from the viewpoint of the Legend of Holy Grail's Knight above mentioned, the teaching is under peace with mutual understanding each country beyond these problems, and not using military power.

The real mission that Lambuth as Holy Grail's Knight came to Japan at the time, and to build Kwansei-Gakuin is for building World Peace and Coexistence in and from Japan through Methodism to Christ's blood and his sacrifice expressed by Holy Grail Mass under the compassion, and evading War (World War).

Thus, the Mission of Kwansei-Gakuin University in nowadays becomes clearly under the Motto Mastery for Service, is to bring peace in Japan and another country. For example, if a serious and critical problem using military power happened them, Kwansei-Gakuin's mission is to become peacekeeper and rebuild peace as World Citizen with the Spirit of Legend of Holy Grail's Knight and, the mind of Jesus Christ which John Wesley said the Christian Perfection ${ }^{34}$.

\section{References}

Kent, John. Wesley and the Wesleyans (Cambridge University Press, 2002)

Robert G. Tuttle. John Wesley, His life and Theology (Michigan, 1978)

Monk, Robert.C, John Wesley His Puritan Heritage, $2^{\text {nd }}$ edition (London, 1999)

Herbert B. McGonigle, Sufficient saving grace: John Wesley's evangelical Arminianism (Paternoster, 2001)

Hahn, Hans-Christoph \& Reichel, Hellmut (Hrsg), Zinzendorf und die Herrnhuter Brüder, Quellen zur Geschichte der Brüder-Unität von 1722 bis 1760 (Hamburg, 1977)

Rubin, Miri, Corpus Christi, The Eucharist in late Medieval Culture (Cambridge University Press, 1991)

Adams, M Marilyn, Some Later Medieval Theories of the Eucharist (Oxford University Press, 2010)

O'Connor, S.J John, The Eucharist in the Primitive Church (New Jersey, 1965)

Bayerische Staatskanzlei (Hrsg), Herzöge und Heilige. Das Geschlecht der Andechs-Meranier im europäischen Hochmittelalter (München, 1993)

Hennig, L. Die Andechs-Meranier in Franken. Europäisches Fürstentum im Hochmittelalter (Mainz, 1998)

Wolfram von Eschenbach, Parzival I, Parzival II (Frankfurt am Main, 2006)

Lupack, Alan, The Oxford Guide to Arthurian Literature and Legend (Oxford University Press, 2007)

Chrétien de Troyes, Le Roman de Perceval ou Le Conte du Graal (Stuttgart, 2009)

Hammond, Geordan, John Wesley in America: restoring primitive Christianity (Oxford University Press, 2014)

Barber, Richard, The Holy Grail -The History of a Legend (Penguin, 2004)

Michael Baigent, Richard Leigh, Henry Lincoln, Holy Blood, Holy Grail (New York,1982)

Turner, J. Munsey, John Wesley: the evangelical revival and the rise of Methodism in England (Epworth Press, 2002)

Leslie F. Church, Knight of the burning heart: the story of John Wesley (Epworth Press, 1959)

Raedel, Christoph, Methodistische Theologie im 19 Jahrhundert (Göttingen, 2004)

Trübsbach, Rainer, Geschichte der Stadt Bayreuth (Bayreuth, 1993)

Csampai, A. \& Holland, D. Parsifal Texte,Materialien,Kommentare (Hamburg, 1984)

Kawanishi Takao. 'Richard Wagner's Parsifal at Bayreuth and 21st century in the World- From the viewpoint "Mitleid(compassion)" using Interdisciplinary Studies -,' Academic Journal of Interdisciplinary Studies, Vol.4, No.10(2013)

Norwood, F Abbott, The Story of American Methodism (Nashville, 1989)

Kwansei Gakuin, Kwansei Gakuin University Overview 2013

Pinson W. Willam, Walter Russell Lambuth, Prophet and Pioneer (Kwansei Gakuin University Press, 2004)

Kwansei Gakuin (ed), Daigaku toha Nanika: What is University (Hyogo, 1975)

Kwansei Gakuin, The Spirit of Kwansei Gakuin, -125 Kwansei Gakuin 1889-2014-.

Rudolf Steiner, Christus und die geistige Welt: Von der Suche nach dem heiligen Gral (Steiner Verlag, 2003)

John Wesley, Thos. O. Summers(ed.), A plain account of Christian perfection (House of the M.E. Church. South, 1889)

Kawanishi Takao, Study of the Legend of Holy Grail's Knight (Doctorate Dissertation) , (Kwansei Gakuin University Press, 2016)

Kawanishi. 'Study of the Legend of Holy Grail's Knight and Emperor Friedrich II by the European House of Andechs Meranien -From the viewpoint their aim for ending of International Religious War "the Crusades"in 12-13th century-,' Mediterranean Journal of Social Sciences, Vol.2, No.9(2013)

Kawanishi. 'Historical Studies about relationship between Legend of European Holy Grail's Knight and City of Bayreuth in Germany-

34 Wesley, Summers(ed.), A plain account of Christian perfection. 
from "Perceval" to "Parzival", and"Parsifal" -,' Studies in Comparative Culture , No.99 (2011)

Kawanishi. 'Die Stadt Bayreuth und Richard Wagner,' Germanistik Kyoto, Nr.9 (2008)

\section{Biography}

\section{Dr. KAWANISHI Takao}

Ph.D. Fellow of Kwansei-Gakuin University, Special Inter-Institutional Research Fellow, International Research Center for Japanese Studies (NICHI BUNKEN) in Japan, Historischer Verein für Oberfranken e. V. in Germany, Allgemeine Anthroposophische Gesellschaft in Switzerland

\section{Main abroad Study about this article,}

University of Oxford (Christ Church, Lincoln College, Mansfield College, Bodleian Library \& Radcliffe Camera) in Britain Harvard University (as Visiting Researcher of Harvard College Library) in USA

\section{Academic speeches about this article at international conference,}

Wesley in Oxford and the Legend of Holy Grail's Knight -A Research about the Root of Methodism from the European Continent, via England and America, to the World-, KAWANISHI Takao, 8th Global Conference on Multiculturalism, Conflict and Belonging, MCB8 in Oxford University Mansfield College, UK, Sept 2014 USA and the Legend of Holy Grail's Knight: Walter Russell Lambuth as "Parsifal", KAWANISHI Takao, 3rd 21st Academic Forum Conference in The Joseph B. Martin Conference Center, Harvard University, USA, Sept 2015 